\title{
The diversity of sex steroid action: novel functions of hydroxysteroid (17 $\beta$ ) dehydrogenases as revealed by genetically modified mouse models
}

\author{
Taija Saloniemi ${ }^{1}$, Heli Jokela ${ }^{1}$, Leena Strauss ${ }^{1,2}$, Pirjo Pakarinen ${ }^{1,2}$ and Matti Poutanen ${ }^{1,2}$ \\ ${ }^{1}$ Department of Physiology, Institute of Biomedicine, University of Turku, Kiinamyllynkatu 10, FI-20014 Turku, Finland \\ ${ }^{2}$ Turku Center for Disease Modeling, University of Turku, Kiinamyllynkatu 10, Fl-20520 Turku, Finland \\ (Correspondence should be addressed to M Poutanen at Department of Physiology, Institute of Biomedicine and Turku Center for Disease Modeling, University of \\ Turku; Email: matti.poutanen@utu.fi)
}

\begin{abstract}
Disturbed action of sex steroid hormones, i.e. androgens and estrogens, is involved in the pathogenesis of various severe diseases in humans. Interestingly, recent studies have provided data further supporting the hypothesis that the circulating hormone concentrations do not explain all physiological and pathological processes observed in hormone-dependent tissues, while the intratissue sex steroid concentrations are determined by the expression of steroid metabolising enzymes in the neighbouring cells (paracrine action) and/or by target cells themselves (intracrine action). This local sex steroid production is also a valuable treatment option for developing novel therapies against hormonal diseases. Hydroxysteroid (17 $\beta$ ) dehydrogenases (HSD17Bs) compose a family of 14 enzymes that catalyse the conversion between the low-active 17-keto steroids and the highly active $17 \beta$-hydroxy steroids. The enzymes frequently expressed in
\end{abstract}

sex steroid target tissues are, thus, potential drug targets in order to lower the local sex steroid concentrations. The present review summarises the recent data obtained for the role of HSD17B1, HSD17B2, HSD17B7 and HSD17B12 enzymes in various metabolic pathways and their physiological and pathophysiological roles as revealed by the recently generated genetically modified mouse models. Our data, together with that provided by others, show that, in addition to having a role in sex steroid metabolism, several of these HSD17B enzymes possess key roles in other metabolic processes: for example, HD17B7 is essential for cholesterol biosynthesis and HSD17B12 is involved in elongation of fatty acids. Additional studies in vitro and in vivo are to be carried out in order to fully define the metabolic role of the HSD17B enzymes and to evaluate their value as drug targets.

Journal of Endocrinology (2012) 212, 27-40

\section{Introduction}

Imbalanced action of sex steroid hormones, i.e. androgens and estrogens, is involved in the pathogenesis of various severe diseases in humans. Hormone-dependent cancers are commonly lethal both in women and in men, with breast cancer being the most prevalent cancer in women and prostate cancer in men in several Western countries (http://info.cancerresearchuk.org/cancerstats/). In addition, there are various other common hormone-dependent diseases, such as polycystic ovary syndrome (PCOS) and endometriosis, having poorly understood aetiology and

This paper is one of the three papers that form part of a thematic review section on the diversity of sex steroid action. The Guest Editor for this section was Matti Poutanen, University of Turku, Finland; he was not involved in the handling of this paper, on which he is listed as an author. lacking efficient pharmacological treatments (Giudice 2010, Goodarzi et al. 2011). The ovaries and testes are the main sources of the circulating sex steroids. However, changes in circulating hormone concentrations do not explain all physiological and pathological processes observed in hormone-dependent tissues. A more inclusive explanation is provided by paracrine and intracrine action of the sex steroids, namely the regulation of intratissue hormone concentrations by the expression of steroidogenic enzymes in the neighbouring cells and/or by target cells themselves, respectively. Interfering with the local sex steroid production using pharmaceutical compounds is also a valuable treatment option for developing novel therapies against hormonal diseases (Labrie 2007). Among the steroid metabolic enzymes, hydroxysteroid (17 $\beta$ ) dehydrogenases (HSD17Bs) compose a family of enzymes that catalyse the conversion between the low-active 17-keto steroids and the highly active 
$17 \beta$-hydroxy steroids. The enzymes, thus, catalyse the reactions between oestrone $\left(\mathrm{E}_{1}\right)$ and estradiol $\left(\mathrm{E}_{2}\right)$, androstenedione (A-dione) and testosterone, and $5 \alpha$-androstanedione (5 $\alpha \mathrm{A}$-dione) to dihydrotestosterone (DHT). However, in addition to their HSD17B activity, certain HSD17B enzymes have also shown to be involved in other metabolic pathways including the synthesis of lipids and cholesterol, for example. At present, 14 mammalian HSD17Bs have been identified. These enzymes possess variable sequence homology, expression pattern (Table 1), cofactor preference, substrate specificity and subcellular localisation (Peltoketo et al. 1999a, Lukacik et al. 2006, Möeller \& Adamski 2006, Wu et al. 2007, Meier et al. 2009, Mindnich \& Adamski 2009, Möeller \& Adamski 2009, Persson et al. 2009). All except one of the HSD17Bs belong to the short-chain dehydrogenase/ reductase family, while HSD17B5 is a member of the aldoketo reductase family. Numerous studies have indicated the expression of various HSD17Bs in sex steroid target tissues. Several of these enzymes are also considered as promising drug targets, and inhibitors are under development, for example for HSD17B1, HSD17B2, HSD17B3, HSD17B5, HSD17B7, HSD17B10 and HSD17B12 (Bagi et al. 2008, Chen et al. 2008, Day et al. 2008a,b, Hsieh \& Ryan 2008, Fournier \& Poirier 2009, Laplante et al. 2009, Sasano et al. 2009). Genetically modified (GM) mice provide an elegant approach to identify novel and unknown functions for genes, and the approach is also successfully used to validate novel drug targets. In this review, we summarise the recent data obtained for the role of HSD17B1, HSD17B2, HSD17B7 and HSD17B12 enzymes in various metabolic pathways and their physiological and pathophysiological roles as revealed by the recently generated GM mouse models.

\section{Enzymatic activities}

\section{HSD17B1}

Based on the in vitro studies, human (h) HSD17B1 has been considered to be highly estrogen specific, with markedly lower catalytic efficacy towards androgenic substrates (Poutanen et al. 1993, Miettinen et al. 1996a, Peltoketo et al. 1999b). Structural studies have also revealed that the substrate-binding site in hHSD17B1 is highly complementary to estrogenic substrates (Azzi et al. 1996, Lin et al. 2006). The enzyme catalyses both oxidative (17-hydroxy to 17-keto) and reductive (17-keto to 17 -hydroxy) $17 \beta$-hydoxysteroid dehydrogense activity with a proper cofactor added in vitro. However, in cultured cells, the hHSD17B1 has been shown to catalyse predominantly the reductive reaction (Poutanen et al. 1993, Miettinen et al. 1996a,b, Puranen et al. 1997, Day et al. 2008b), and recent studies have further provided evidence for reductive HSD17B activity for hHSD17B1 in vivo. For example, MCF-7 cells stably transfected with hHSD17B1 presented with increased estrogen-dependent tumour growth in immunodeficient mice in the presence of
$+$

$+++++++++++++++++++$ $++++++++++++++++++++$

$+++++++++++++++++++$ $++++++++++++++++++++$ $++++++++++++++++++++$

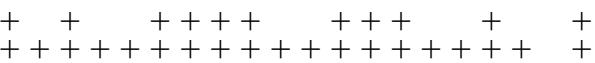
$+++++++++++++++++++$ $+++++++++++++++++\quad+$ $+++++++++++++++++++$ $+++++++++++++++++++$

$+\quad+++\quad+\quad+$ $++++++++++++++++++++$ $+++++++++++++++++++$

$+\quad+\quad++++\quad+++++\quad+$ $+++++++++++++++++++$ $++++++++++++++++++++$

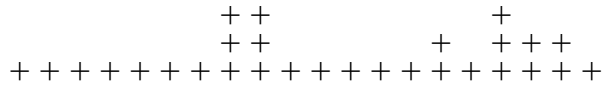

$+++++++++++++\quad++\quad+++$
$++++t+2$

$+++++++++++++++++++$ $+++++++++++++++++++$ $++++++++++++++++++++$

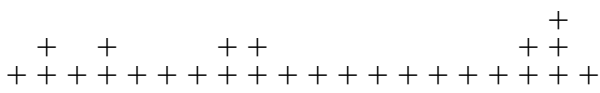

$++t+++++++++++++++t$

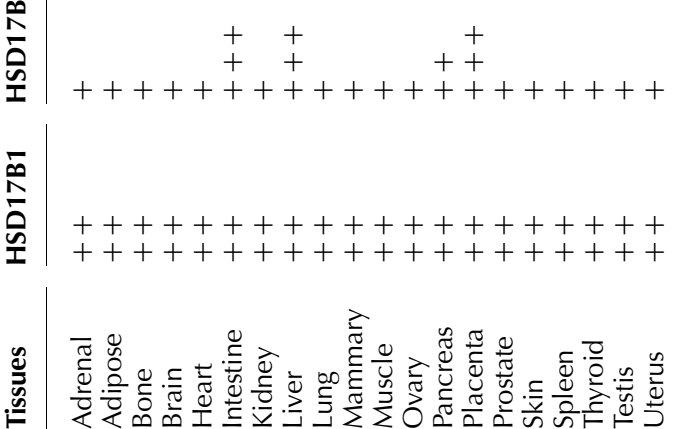


$\mathrm{E}_{1}$, under condition where no such effect was detected with the parental MCF-7 cells lacking significant HSD17B activity (Husen et al. 2006). Furthermore, hHSD17B1-dependent tumour growth was significantly reduced by HSD17B1 inhibitor treatment (Husen et al. 2006). In addition to HSD17B1, several other hHSD17Bs are capable of converting $\mathrm{E}_{1}$ to $\mathrm{E}_{2}$, including HSD17B7 (Torn et al. 2003) and HSD17B12 (Luu-The et al. 2006), but the role of these enzymes in the extra-gonadal $\mathrm{E}_{2}$ formation still remains unclear. Although hHSD17B1 expression in various peripheral tissues is low, its catalytic efficacy is markedly higher than those measured for HSD17B7 and HSD17B12 (Luu-The et al. 2006), suggesting an important role for HSD17B1 in peripheral $\mathrm{E}_{2}$ formation. We have recently analysed the role of hHSD17B1 in estrogen metabolism in vivo using transgenic (TG) mice ubiquitously over-expressing the hHSD17B1 under the chicken $\beta$-actin promoter (HSD17B1TG mice). In these mice, a small dose of $\mathrm{E}_{1}$ treatment induced a markedly increased uterine weight under a condition where no such effect was observed in wild-type (WT) mice (Saloniemi et al. 2010). Furthermore, an increased $E_{2}$ concentration, in response to $\mathrm{E}_{1}$ treatment, was apparent in all TG tissues with the exception of the ovaries (Saloniemi et al. 2010) that presented a high endogenous Hsd17b1 expression (Nokelainen et al. 1996). These data further demonstrated the ability of hHSD17B1 to enhance estrogen action in target tissues in the presence of low-active $\mathrm{E}_{1}$. Moreover, over-expression of $\mathrm{hHsd} 17 \mathrm{~b} 1$ in TG mice under a MMTV promoter resulted in significantly increased reductive estrogenic activity in vivo, and the activity was significantly decreased after treating the mice with HSD17B1 inhibitors (Lamminen et al. 2009). These data suggest that HSD17B1 plays a major role in determining the gradient between the $\mathrm{E}_{2}$ concentrations in serum and peripheral tissues. This type of gradient has been reported, e.g. for breast cancer tissue (van Landeghem et al. 1985, Lønning et al. 2009), where the tissue presents with high HSD17B1 expression (Poutanen et al. 1993, Miyoshi et al. 2001, Shibuya et al. 2008).

There is a clear difference in the substrate specificity between the human and the rodent HSD17B1 enzymes; the catalytic efficacy for the rodent enzyme in vitro is similar for both androgens and estrogens (Nokelainen et al. 1996). However, the human enzyme has also been shown to catalyse conversion of A-dione to testosterone (Puranen et al. 1997), and the formation of androstenediol from dehydroepiandrosterone (DHEA) and $3 \beta$-androstanediol from DHT (Lin et al. 2006), but the significance of these activities in vivo has been unclear. Interestingly, despite the high $\mathrm{Km}$ value measured in vitro for hHSD17B1 towards A-dione (Puranen et al. 1997, Lin et al. 2006), in cultured cells, the activity obtained for A-dione to testosterone conversion was 20\% of that observed for $E_{1}$ to $E_{2}$ conversion (Poutanen et al. 1993). This suggested that the hHSD17B1 possesses considerable androgenic activity with the preference for estrogenic substrates. Accordingly, a significantly increased conversion of A-dione to testosterone was observed in both female and male HSD17B1TG mice, together with significantly increased testosterone concentration in foetal TG females (Saloniemi et al. 2007). In summary, the data observed indicate that hHSD17B1 is not fully estrogen-specific but presents with significant androgenic activity.

\section{HSD17B2}

Both human and mouse HSD17B2 enzymes possess oxidative activity and are capable of catalysing in vitro the conversion of the $17 \beta$-hydroxy forms of estrogens and androgens, such as $\mathrm{E}_{2}$, testosterone and DHT to their less active 17-keto forms, $\mathrm{E}_{1}, \mathrm{~A}$-dione and $5 \alpha \mathrm{A}$-dione respectively. The enzyme also possesses $20 \alpha$-HSD activity, thereby activating $20 \alpha$-hydroxyprogesterone to progesterone (Wu et al. 1993, Labrie et al. 1995). Therefore, the HSD17B2 potentially regulates the ligand availability for several nuclear receptors (Fig. 1).

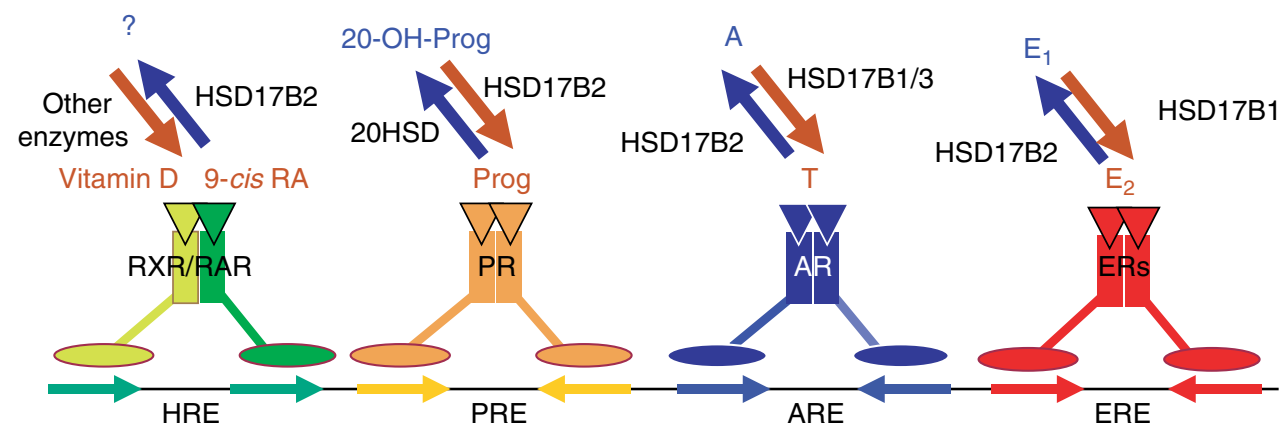

Figure 1 The HSD17B2 potentially regulates the ligand availability for several nuclear receptors (ERs, estrogen receptors, $\alpha$ and $\beta$ ); $A R$, androgen receptor; PR, progestin receptor; RAR, retinoid acid receptor; $R X R$, retinoid $X$ receptor) simultaneously. The enzyme has shown to inactivate estradiol $\left(E_{2}\right)$ to oestrone $\left(E_{1}\right)$ and testosterone $(\mathrm{T})$ to androstenedione $(\mathrm{A})$, to activate the $20 \alpha$-hydroxyprogesterone 1 (20-OH-Prog) to progesterone (prog), and is potentially involved in the metabolism of retinoids, such as 9-cis-retinal (9-cis-RA). The other HSD17Bs and the 20 $\alpha$-hydroxysteroid dehydrogenase (20HSD) potentially catalyse the opposite reactions, and thus, the balance between the oxidative and reductive enzyme activities determines the ligand concentrations at the target cells. 
HSD17B2 is localised in the endoplasmic reticulum, and it is widely expressed in various estrogen and androgen target tissues both in humans and in rodents including breast (Haynes et al. 2010), endometrium (Casey et al. 1994), placenta (Mustonen et al. 1998b) and prostate (Elo et al. 1996). The data, thus, suggest a role for the enzyme in the hormonal regulation of these tissues. However, the role of HSD17B2 in various metabolic pathways is only superficially known, and further studies have indicated that the enzyme is also expressed throughout the gastrointestinal tract and in the liver both in mice and in humans (Miettinen et al. 1996a, Mustonen et al. 1997a,b, 1998a, Sano et al. 2001). Phylogenic analyses have indicated that HSD17B2 is a close homologue of retinoid-converting enzymes and presents with a high sequence similarity to retinol dehydrogenase type 1 (Chai et al. 1995a,b, Simon et al. 1995). In addition, studies have shown that retinoic acid (RA) induces expression of HSD17B2 in a dose- and time-dependent manner in human endometrial epithelial (Cheng et al. 2008) and placental cells (Su et al. 2007). In order to test the activity of hHSD17B2 in vivo, we generated TG mice ubiquitously expressing the enzyme under the chicken $\beta$-actin promoter (Zhongyi et al. 2007). In these mice, the conversion of $E_{2}$ to $\mathrm{E}_{1}$ was followed in vivo by injecting tritium-labelled $\mathrm{E}_{2}$ into the mice, and a significantly increased oxidative HSD17B activity was detected in the TG mice compared with WT mice. The results, thus, confirmed that the HSD17B2 present with oxidative HSD17B activity in vivo. However, the enzymatic activity in the generated TG lines was relatively low. Owing to the possibility of inducing embryonic lethality in TG mice with high expression of HSD17B2, we also dissected a set of TG founder mice at the end of embryonic life. In these foetuses, a high $\mathrm{E}_{2}$ to $\mathrm{E}_{1}$ conversion was detected, further confirming the $\mathrm{E}_{2}$ to $\mathrm{E}_{1}$ reaction catalysed by HSD17B2. However, in the generated TG mouse lines, the male mice presented with severe phenotypic alterations (see below) without significantly altered serum LH, FSH or testosterone. Furthermore, no significant alterations were observed in intratissue testosterone concentrations between the TG and the WT males measured in several peripheral tissues. However, there was a trend to lower testosterone concentration in the TG tissues compared with the WT tissues. Only a limited suppression of androgen action was confirmed by analysing the expression of the androgendependent genes in the prostate and epididymis. Similar to that observed for certain androgen-dependent genes in the males, the expression of several estrogen-dependent genes in the mammary glands were significantly down-regulated by the local expression of HSD17B2 in the HSD17B2TG mammary glands transplanted in WT hosts. Thus, the data suggest a modulatory role for HSD17B2 in the expression of androgen and estrogen target genes, while sex steroid-independent mechanisms are partially responsible for the phenotypic alterations observed in the HSD17B2TG mice.

\section{HSD17B7}

The HSD17B7 enzyme was first characterised as a prolactin receptor-associated protein in the rat corpus luteum (Duan et al. 1996), although its role in prolactin signalling has remained unknown. The rodent (Nokelainen et al. 1998) and human (Torn et al. 2003) HSD17B7 enzymes catalyse the conversion of $\mathrm{E}_{1}$ to $\mathrm{E}_{2}$ in vitro, and based on the high expression of HSD7B7 in mouse ovary, the enzyme is considered to be important in $\mathrm{E}_{2}$ production, especially during pregnancy (Nokelainen et al. 1998, 2000). Also a shorter splice variant of hHSD17B7 has been identified (Liu et al. 2005), which has also been observed to catalyse the conversion of $E_{1}$ to $E_{2}$ in cultured cells. However, opposite results have been reported, as in some studies the truncated HSD17B7 protein was found to be inactive (Marijanovic et al. 2003). Owing to its amino acid sequence similarity with the yeast ERG27 protein, the HSD17B7 enzyme was also suggested to possess a 3-ketosteroid reductase activity (Breitling et al. 2001a,b, Marijanovic et al. 2003). Accordingly, in vitro, both the human and the mouse HSD17B7 enzymes have been shown to catalyse the conversion of zymosterone to zymosterol (Marijanovic et al. 2003), an essential reaction in the cholesterol biosynthesis. A role for mouse HSD17B7 in cholesterol biosynthesis was also suggested by the studies showing a similar expression pattern for HSD17B7 and the known cholesterogenic enzymes during mouse embryonic development (Laubner et al. 2003, Marijanovic et al. 2003). However, there are certain differences between the HSD17B7 expression compared with the gene expression of the other cholesterol biosynthetic enzymes, suggesting additional roles for HSD17B7. Analysis of the concentration of cholesterol and various cholesterol biosynthesis intermediates in the WT, heterozygous and HSD17B7KO mouse embryos evidently showed that HSD17B7 is essential for cholesterol biosynthesis also in mice in vivo (Jokela et al. 2010). The data indicated that HSD17B7 catalyses the conversion of zymosterone to zymosterol, as in the knockout (KO) mouse embryos, the earlier intermediates such as lanosterol and squalene accumulated, and cholesterol, lathosterol and desmosterol (representing the later steps of cholesterol biosynthesis) were markedly reduced. Furthermore, the data show that lack of HSD17B7 was not efficiently compensated by other enzyme activities. The present data, thus, unquestionably show the in vivo role of HSD17B7 in cholesterol biosynthesis in mice, while its role in $\mathrm{E}_{2}$ production in vivo remains to be further clarified (Fig. 2).

\section{HSD17B12}

The mammalian HSD17B12 was initially characterised as a 3-ketoacyl-CoA reductase, involved in the long-chain fatty acid synthesis (Moon \& Horton 2003). Both the human and the mouse HSD17B12 share a 40\% sequence similarity with HSD17B3, and the data indicate that HSD17B12 is an ancestor of HSD17B3 (Mindnich et al. 2004). In humans, the 


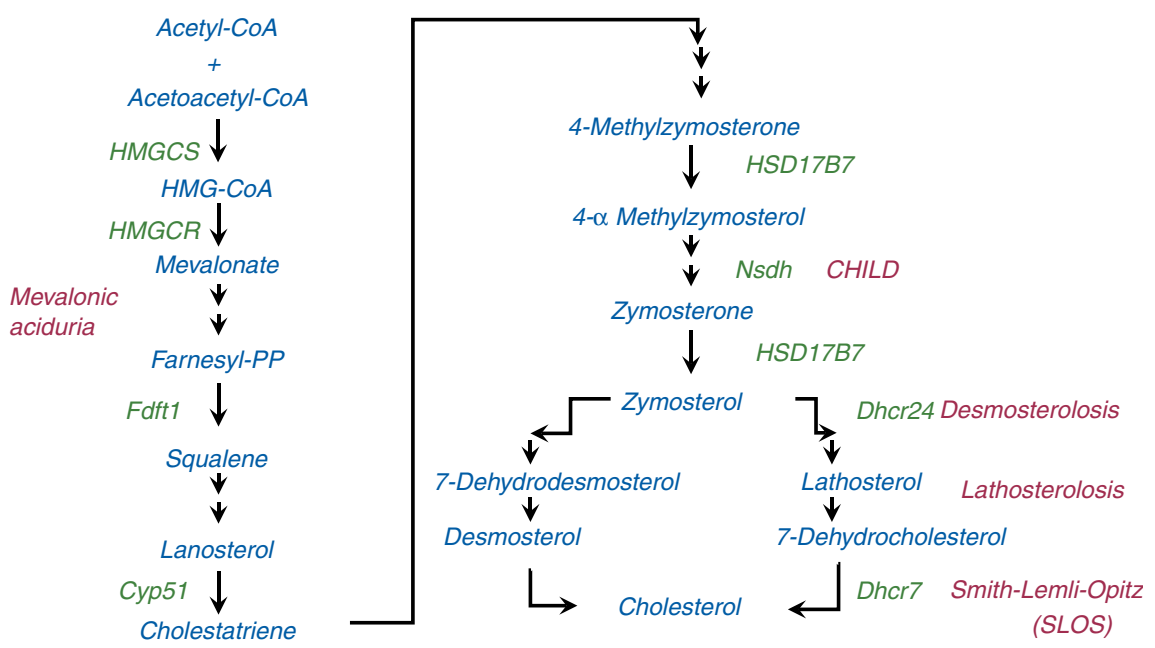

Figure 2 Cholesterol synthesis pathway: the enzymes involved in the synthesis and the syndromes associated with the enzyme defects. The data obtained in vitro and in the HSD17B7KO mice in vivo indicate a role for HSD17B7 in zymosterol synthesis, and thus, $\mathrm{Hsd} 17 \mathrm{~b} 7$ is a new candidate gene for inborn errors of cholesterol metabolism. The cholesterol synthesis with intermediates is shown in blue, the enzymes involved are indicated in green and the characterised inborn errors of cholesterol synthesis are indicated in red.

highest expression of HSD17B12 is detected in the tissues involved in lipid metabolism, including the liver, kidney and muscle (Sakurai et al. 2006). In mice, the expression has also been detected in the brown and white adipose tissue (Moon \& Horton 2003, Sakurai et al. 2006, Blanchard \& Luu-The 2007). Studies on zebra fish have, furthermore, supported the role of HSD17B12 in fatty acid synthesis (Mindnich et al. 2004), and studies with LET-767, the Caenorhabditis elegans ortholog of HSD17B12, have shown that the enzyme is required for the production of branched-chain and longchain fatty acids in vivo (Entchev et al. 2008). HSD17B12 expression is also regulated by sterol regulatory elementbinding proteins, identically to that shown for several genes involved in fatty acid and cholesterol biosynthesis (Nagasaki et al. 2009). Interestingly, a reduced expression of HSD17B12 in cultured breast cancer cells results in significant inhibition of cell proliferation that is fully recovered by supplementation of arachidonic acid (AA; Nagasaki et al. 2009). Our studies in embryonic stem (ES) cells with reduced expression of Hsd17b12 (Rantakari et al. 2010) further indicated an imbalanced fatty acid synthesis. In these cells, the relative amount of linoleic acid was unchanged while the amount of AA was significantly decreased compared with the WT ES cells, suggesting that HSD17B12 deficiency caused insufficient synthesis of AA. In addition to its putative role in fatty acid synthesis, human HSD17B12 has been shown to catalyse the conversion of $E_{1}$ to $E_{2}$ in cultured cells (Fig. 3), and the enzyme was suggested to be a major enzyme converting $E_{1}$ to $\mathrm{E}_{2}$ in postmenopausal women (Luu-The et al. 2006). However, neither over-expressed nor reduced expression of $H s d 17 B 12$ affects the $\mathrm{E}_{2}$ production in cultured breast cancer cells (Day et al. 2008b).

\section{Phenotypic alterations in GM mice for HSD17B enzymes}

\section{TG mice}

HSD17B1TG mice Several studies (Stinnakre 1975, Wolf et al. 2002, 2004, Welsh et al. 2008) have shown that excess of androgens during foetal life disturbs normal development, resulting, for example, in masculinisation of the female reproductive tract. This is also suggested by the data obtained from human patients with congenital adrenal hyperplasia. In these patients, the female foetuses have increased adrenal testosterone production, resulting in masculinisation of the external genitalia (Merke \& Bornstein 2005). Along with the significant androgenic activity of hHSD17B1 and with the increased foetal testosterone concentration, the TG female mice expressing hHSD17B1 ubiquitously presented with androgen-dependent phenotypic alterations, such as increased anogenital distance, suppressed nipple development, lack of vaginal opening and the combination of vagina with the urethra (Table 2). These alterations observed in the HSD17B1TG females were effectively rescued by prenatal anti-androgen (flutamide) treatment, further confirming the dependence of these phenotypes on androgens (Saloniemi et al. 2007, 2009). Androgen receptor (AR) is expressed in both female and male reproductive tissues during development, and consequently, the female reproductive tract responds also to androgens (Bentvelsen et al. 1995). Nipple development in mice has also been shown to be androgen dependent. Male rodents normally lack nipples but, for example in rats, those are formed in under-masculinised males, e.g. after prenatal flutamide treatment (Miyata et al. 2002, Foster \& Harris 2005), or in the TG mice having 


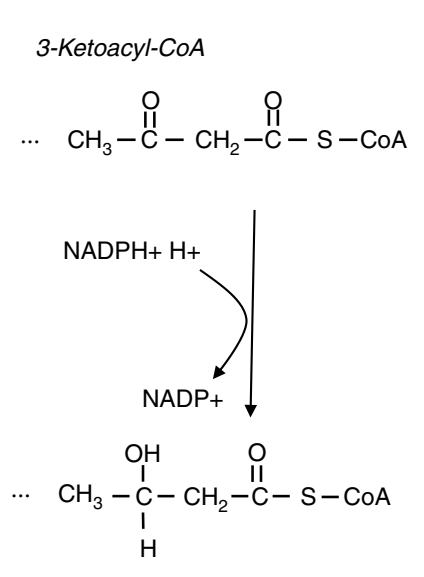

3-Hydroxyacyl-CoA

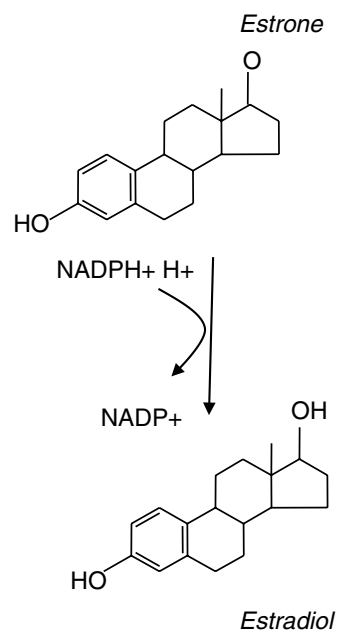

Figure $3 \mathrm{HSD} 17 \mathrm{~B} 12$ has shown to possess both 3-ketoacyl-CoA reductase activity involved in elongation of free fatty acids, and HSD17B activity converting low-activity sex steroid oestrone to highly active estradiol.

an increased $\mathrm{E}_{2}$ /testosterone ratio due to the expression of P450 aromatase (CYP19A1; Li et al. 2002). Accordingly, prenatal flutamide treatment retained nipple development and rescued vaginal morphology in masculinised HSD17B1TG female mice (Saloniemi et al. 2007, 2009). Interestingly, around the urethra of HSD17B1TG females, we identified an enlarged Skene's paraurethral gland, also referred to as the female prostate. The female prostate has been reported to be present in several species and, similarly to the males, it has been shown to respond to androgens (Santos et al. 2006). In HSD17B1TG females, flutamide treatment also suppressed the gland development (Saloniemi et al. 2007). The fact that placental testosterone concentration was not increased indicated that elevated androgen exposure was not of maternal origin. These data unequivocally show that overexpression of hHSD17B1 leads to increased androgen exposure during embryonic development. However, the source of androgen could not be determined.
Interestingly, the androgen exposure during the second half of pregnancy in the HSD17B1TG mice resulted in benign ovarian serous cystadenomas in adulthood (Saloniemi et al. 2007). These are common, slowly proliferating, benign lesions that can be precursors of ovarian serous borderline tumours, which can, in turn, progress to low-grade carcinomas (Cheng et al. 2004). However, no progression for cancer was observed in the TG females, suggesting that additional factors are required for malignant transformation of the ovarian surface epithelium. The development of the cystadenomas in HSD17B1TG females was prevented by treating the mice prenatally with an anti-androgen (flutamide) or by transplanting WT ovaries to HSD17B1TG females. Based on the data, it is evident that there is a connection between the foetal androgen production in the HSD17B1TG females and the development of benign serous cystadenomas in the TG mice (Saloniemi et al. 2007). Foetal masculinisation has not been directly linked to ovarian surface epithelial pathologies in humans, but ovarian surface epithelium-lined surface invaginations and epithelial inclusion cysts, which are considered as an initiation site for ovarian carcinogenesis, are more frequent in PCOS patients than in healthy individuals (Auersperg et al. 2001). It has also been shown that ovarian serous borderline tumours are positively associated with a history of PCOS, thus with a history of (foetal) hyperandrogenism (Olsen et al. 2008). HSD17B1 expression has been linked to ovarian epithelial cancers and was shown to positively correlate with an increasing malignancy of ovarian surface epithelial tumours (Sasano et al. 1996, Blomquist et al. 2002, Chura et al. 2009). Both estrogens and androgens have been associated with ovarian epithelial carcinogenesis (Syed et al. 2001, Ho 2003). Therefore, HSD17B1 may promote ovarian carcinogenesis via increasing estrogen concentration, but also via enhanced androgen production.

The data have shown that over-expression of hHSD17B1 in mice enhances estrogen action in the uterus and, in combination with persistent anovulation, causes endometrial hyperplasia, ranging from simple to complex hyperplasia with atypia (Saloniemi et al. 2010). However, endometrial carcinomas were not observed in HSD17B1TG mice,

Table 2 Sex steroid-dependent phenotypic alterations in various transgenic mice ubiquitously expressing human hydroxysteroid (17 $\beta$ ) dehydrogenase 1

\section{Severity of the phenotypic alteration}

Transgenic mouse lines

Level of transgene expression

Phenotypic alterations in female mice

Anovulation

Lack of nipples

Male-like vaginal/urethral morphology

Longer anogenital distance

Hyperplastic endometrium

Ovarian cysts

Hyperplastic pituitaries

\begin{tabular}{lllll}
\hline 016 & 020 & 012 & 050 & 013 \\
+ & ++ & ++ & +++ & ++++ \\
ND & + & + & ++ & ++++ \\
- & - & - & +++ & ++++ \\
- & - & - & +++ & ++++ \\
ND & ND & ND & +++ & ++++ \\
ND & ND & ND & ++ & ++++ \\
ND & ND & +++ & +++ & ++++ \\
ND & ND & ND & ++++ & ++++ \\
& & & & \\
\hline
\end{tabular}

- , no change; + , mild ++ , moderate; +++ , strong; ND, not determined 
indicating that other mechanisms, such as phosphatase and tensin homologue inactivation, loss of forkhead box $\mathrm{O}$ subclass transcription factor 1 and hyperactivity of the PI3K pathway, are important pathways in endometrial carcinogenesis (Goto et al. 2008). Endometrial hyperplasia in HSD17B1TG mice closely resembled human disease and was efficiently reversed upon normalisation of the estrogen/ progestin ratio in response to either ovulation induction or exogenous progestins, and in addition, they responded to HSD17B1 inhibitor treatment (Saloniemi et al. 2010). The data concerning the expression of HSD17B1 in the human normal and diseased endometrium are not fully conclusive. However, in most of the studies, the HSD17B1 expression is detected in normal endometrium, endometriosis specimens and endometriotic cancer (Mäentausta et al. 1991, 1992, Casey et al. 1994, Zeitoun et al. 1998, Smuc et al. 2006, Dassen et al. 2007, Fechner et al. 2007). Various other HSD17B enzymes including HSD17B2, HSD17B5, HSD17B7 and HSD17B12 have also been detected in the endometrium under different pathological conditions (Rizner et al. 2006, Smuc et al. 2006), endometriosis (Dassen et al. 2007, Delvoux et al. 2009) and PCOS (Bacallao et al. 2008, Leon et al. 2008). Studies have indicated that in the endometrium, the oxidative HSD17B activity is higher than the reductive activity (Delvoux et al. 2007, 2009), while significant reductive activity has also been detected in the human endometrium (Delvoux et al. 2007, 2009). Recent studies in endometrial and cervical cancer cell lines indicate that reductive activity can be inhibited by using the inhibitors of HSD17B1, HSD17B5, HSD17B7 and HSD17B12, indicating that all four enzymes contribute to estrogen synthesis in the cancer cell lines. However, full inhibition was not obtained even when using a combination of the inhibitors, indicating that there are still other HSD17B(s) participating in endometrial estrogen synthesis (Fournier \& Poirier 2009). Thus, combination of the activities of these enzymes ultimately determines the hormonal status of the endometrium and the drug combination to be used. Collectively, the data suggest that HSD17B1 inhibition is one of the several possible approaches to reduce estrogen production both in eutopic and in ectopic endometrial tissue.

HSD17B2TG mice In HSD17B2TG male mice, there were certain phenotypes that prompted us to seek for phenotypes that are not directly known to be related to altered sex steroid action, including a delayed eye opening and growth retardation (Zhongyi et al. 2007). In addition, we have previously found a lack of correlation between HSD17B2 expression and the hormonal status in female rat (Akinola et al. 1997). These observations have also encouraged us to seek other pathways putatively affected by HSD17B2 expression. Thus, it has been fascinating to note that certain observed phenotypes in HSD17B2TG mice expressing the enzyme under a ubiquitous promoter, such as the growth retardation, resemble the phenotypes observed in a variety of RA receptor knockout mice (Lohnes et al. 1993, Lufkin et al.
1993, Kastner et al. 1994, 1996, Ghyselinck et al. 1997). Vitamin A exposure induces disruption of spermatogenesis, while only the undifferentiated spermatogonia remain in the seminiferous tubuli. Accordingly, providing proper amount of RA to vitamin A-deficient animals restores and synchronises spermatogenesis in mice (Gaemers et al. 1996, 1998a, Schrans-Stassen et al. 1999). In order to analyse whether HSD17B2 participates in the retinoid metabolism, retinoid acid receptor agonist (TTNPB) has been provided for the HSD17B2TG males, and interestingly, the TTNPB treatment efficiently reduces the seminiferous tubule damage observed in the HSD17B2TG males.

In addition to males, the HSD17B2TG female mice displayed delayed eye opening, and some mice were present with squint appearance of the eyes long after the normal age of eye opening. The eyes are known to be the most sensitive organ to retinol deficiency, and it is considered to be the first place of malformations in vitamin A-deficient foetuses (Lohnes et al. 1994, Grondona et al. 1996). Moreover, various retinoid receptor mutant mice (Kastner et al. 1994, Lohnes et al. 1994) have implicated the role of retinoid signalling at most steps of prenatal eye morphogenesis and eye development.

HSD17B1 and HSD17B2 bi-TG mice To study whether the phenotypic alterations observed in the HSD17B2TG mice could be rescued by the expression of HSD17B1 (and vice versa), the bi-TG (HSD17B1HSD17B2TG) mice were generated by utilising mice expressing the transgenes under the same promoter (Shen et al. 2009). The bi-TG mice showed features of both HSD17B1TG and HSD17B2TG mice, while the phenotypes observed in the single TG mice were not efficiently rescued in the bi-TG. The female bi-TG mice were masculinised similar to the HSD17B1TG mice (Saloniemi et al. 2007), but were growth retarded at prepubertal and young adult age, and had extensive lobulo-alveolar development similar to the HSD17B2TG mice (Zhongyi et al. 2007, Shen et al. 2009). Furthermore, the bi-TG females did not present with vaginal opening, while they showed improper separation of vagina and urethra, suppressed nipple development and ovarian benign serous cystadenomas, similar to that previously reported for HSD17B1TG females. However, androgendependent increase in the anogenital distance and reduced uterus weight of HSD17B1TG females were partially rescued in bi-TG mice. Like HSD17B2TG males, bi-TG males also showed growth retardation and severely disrupted spermatogenesis. Histological analysis showed that at the age of 6 months, seminiferous tubules were severely atrophic and contained mostly only Sertoli cells. The data suggest that certain phenotypic characteristics in the HSD17B1TG and HSD17B2TG lines are caused by different signalling pathways (Shen et al. 2009). The most notable changes in the HSD17B1TG mice are well explained by alterations in sex steroid action, whereas in the HSD17B2TG mice the connection to sex steroids is weaker. 


\section{Knockout mice}

As described above, the recent characterisation of the activities of some HSD17B family members, together with the data obtained in TG mice, have provided evidence for the fact that the substrate specificity of HSD17B enzymes is broader than initially expected. In line with these observations, the embryonic lethal phenotypes observed in the HSD17BKO2, 7 and 12 mice do not mimic the phenotype alterations observed in mice deficient in estrogen receptor- $\alpha$ (Esr1), estrogen receptor- $\beta$ (Esr2) and $A R$ (Matsumoto et al. 2003, Hewitt et al. 2005, Zhao et al. 2008, Kerkhofs et al. 2009), or those over-exposed to sex steroids. This further points towards other enzymatic activities associated with these HSD17B enzymes.

Hsd17B2KO mice In addition to several other tissues, Hsd17b2 is expressed in the placenta, and there is also a marked expression of the enzyme during embryogenesis. During the placental development, the mouse Hsd17b2 expression presents with differential distribution among the various placental compartments. The data have revealed that during the mid-gestation, the HSD17B2 enzyme is present in the trophoblast giant cells (Mustonen et al. 1997b), while at the embryonic day (E) $12 \cdot 5$, the expression emerges at the labyrinth region. Also at the end of pregnancy, the expression is at its strongest in the labyrinth region (Mustonen et al. 1997b). Furthermore, the Hsd17b2 expression appears simultaneously both in the placenta and in the foetal liver and intestine. This, together with the observed oxidative HSD17B activity of the enzyme, has been the basis for the hypothesis, suggesting a role for the enzyme in lowering the sex steroid exposure of the foetus (Tong et al. 2005). The importance of the regulation of foetal estrogen exposure is shown by the results indicating that estrogen excess in Sult1e 1 $K O$ mice results in placental thrombosis and spontaneous loss of the foetus (Mahendroo et al. 1997). However, the placentas of HSD17B2KO mice displayed histological malformations, while no signs of thrombosis were observed. Furthermore, the treatment of pregnant female mice with an anti-estrogen or with progesterone did not prevent the foetal loss of the HSD17B2KO mice (Rantakari et al. 2008). Thus, the cause of embryonic deaths in the HSD17B2KO mice is likely not due to the lack of progesterone or due to an increased action of estrogens. Interestingly, the embryonic deaths of the HSD17B2KO mice occur at the time when there is a shift in the $H s d 17 b 2$ expression from the maternal to the foetal part of placenta and manifestation of the $H s d 17 b 2$ expression in the foetus. Similar to those identified in the TG mice expressing hHSD17B2 (Zhongyi et al. 2007), certain phenotypic alterations in the HSD17B2KO mice closely resembled those identified in mice with altered RA metabolism (Cohlan 1953, Lohnes et al. 1994, Gaemers et al. 1998a,b). Thus, the defects in the placenta development in the HSD17B2KO mice might be due to simultaneously altered actions of RA and sex steroids. In vitro studies have, furthermore, shown that retinoids induce $H s d 1762$ expression and enzyme activity in a dose- and time-dependent manner (Ito et al. 2001).

HSD17B7KO mice As shown above, in addition to catalysing the reactions involved in sex steroid metabolism, HSD17B7 catalyses the conversion of zymosterone to zymosterol both in vitro and in mice in vivo. The concentrations of the cholesterol biosynthesis intermediates measured in HSD17B7KO embryos were altered (Jokela et al. $2010)$ in the manner expected by the activity for the enzyme based on the data obtained in vitro (Marijanovic et al. 2003). The lack of HSD17B7 resulted in a marked blockage in foetal de novo cholesterol synthesis, while the amount of total cholesterol was normal in the HSD17B7KO embryos, as measured at E10 5. This, together with other studies, suggests that the pregnant female supplies most of the cholesterol present in the embryo for the first 10-12 days of pregnancy (Tint et al. 2006). However, the data indicated that the maternal cholesterol supply is not sufficient to support the neuroectodermal survival and cardiovascular differentiation in the absence of foetal HSD17B7 activity (Jokela et al. 2010). In addition to HSD17B7, 7-dehydrocholesterol reductase (Dhcr7) is one of the enzymes in the final steps of cholesterol synthesis. Interestingly, mice deficient in Dhor 7 survive until birth (Fitzky et al. 2001), while the HSD17B7KO mice present with embryonic lethality (Shehu et al. 2008, Jokela et al. 2010). This data suggest that, in contrast to 7-dehydrocholesterol, zymosterone is not able to compensate for the lack of cholesterol in embryonic development or that zymosterol has other vital functions apart from its role as a cholesterol biosynthesis intermediate. In connection to this, it has been shown that zymosterol is one of the liver $\mathrm{X}$ receptor (LXR) ligands (Yang et al. 2006). The Lxr-deficient mice, however, do not present with defects in embryonic development (Alberti et al. 2001). In addition, it has to be considered that the accumulation of cholesterol precursors may possess toxic effects on the embryos, as postulated, for example, for Smith-Lemli-Opitz syndrome (Gaoua et al. 1999). However, the mechanisms of such toxic effects have not been presented and the evidence for toxicity in vivo is lacking.

Histological analysis revealed that the $H s d 17 b 7$ deficiency results in defects in the development of front brain hemispheres, related to an increased apoptosis in the neuronal tissues (Shehu et al. 2008, Jokela et al. 2010). The need of de novo cholesterol synthesis in the foetal brain development is supported by the data showing that the blood-brain barrier in mice forms at around E10 (Tint et al. 2006). Furthermore, the cardiovascular system was also affected at E9.5 onwards, as no organised vessels were observed in the HSD17B7KO yolk sac, and the complexity of the vasculature was also reduced in the brain of the KO embryos. Furthermore, heart development was affected, and we observed pericardial effusion, reduced number of myocardial cells and thin pericardium (Jokela et al. 2010). Similar phenotypic alterations, such as malformation of the nervous system, have also been observed in other 
mutant mice with a defect in cholesterol biosynthesis (Liu et al. 1999, Tozawa et al. 1999, Fitzky et al. 2001). Interestingly, the mutant mice deficient in $E b p, S c 5 d$, Dhor24 and Dhor7 survive until birth (Derry et al. 1999, Fitzky et al. 2001, Krakowiak et al. 2003, Wechsler et al. 2003, Mirza et al. 2006), while the HSD17B7KO and mice deficient in the steps prior to the HSD17B7 (Liu et al. 1999, Tozawa et al. 1999, Caldas et al. 2005) present with embryonic lethal phenotypes.

HSD17B12KO mice HSD17B12 has been shown to present with activities involved in fatty acid elongation, particularly in the elongation of essential fatty acids such as AA (Moon \& Horton 2003) and to catalyse the conversion of $\mathrm{E}_{1}$ to $\mathrm{E}_{2}$ (Luu-The et al. 2006). AA is derived from one of the essential fatty acid compounds, linoleic acid, through a series of metabolic steps involving desaturation and subsequent chain elongation (Cook et al. 1991). AA, in turn, gives rise to a whole group of biologically important 20-carbon substances known as the eicosanoids, including prostaglandins, leukotrienes and thromboxanes. These compounds are important for the regulation of a variety of metabolic and physiological processes (Chatzipanteli et al. 1996). The expression pattern of Hsd17b12 further supports its role in lipid metabolism. Both the mouse and the human Hsd17b12 are expressed universally (Sakurai et al. 2006, Blanchard \& Luu-The 2007) but show highest levels in the tissues related to lipid metabolism, including liver, kidney, heart and skeletal muscle (Sakurai et al. 2006). Hsd17b12 is also strongly expressed during mouse development. It is observable in the embryonic ectoderm at E7.5, and high expression is present in the neural tissue from E8.5 onwards (Rantakari et al. 2010). The expression pattern of $H s d 17 b 12$ refers to a role in neuronal development. In addition, Hsd17b12 expression was observed in the yolk sac and in the ectoplacental cone. Analysis of the HSD17B12KO embryos indicated that the embryos initiated gastrulation but further organogenesis was severely disrupted. The HSD17B12KO embryos showed shortened anteriorposterior axis and presented with severe defects in the neuronal development. In addition, they failed to grow several mesoderm-derived structures (Rantakari et al. 2010). Therefore, the embryos at the age of E8·5-E9.5 were void of all normal embryonic structures. Furthermore, the proliferation capacity of the inner cell mass obtained from the HSD17B12KO blastocysts was strongly decreased as analysed in vitro (Rantakari et al. 2010). In line with the suggested function of HSD17B12 in the fatty acid elongation, these phenotypic features observed were similar to those previously reported for the acetyl-CoA carboxylase- $\alpha$ (ACACA, Acc1) null mice (Abu-Elheiga et al. 2005). The brain is rich in structural lipids, and AA and docosahexaenoic acid are the predominant essential fatty acids in the mammalian brain (Crawford et al. 1976, Crawford 1993). Studies have demonstrated that the deficiency of AA leads to neurodevelopmental disorders accompanied by impaired foetal growth and behavioural retardation (Sinclair \& Crawford 1973, Galli
\& Spagnuolo 1976, Leaf et al. 1992, Wainwright et al. 1997, Birch et al. 1998, 2000). Studies with tissue-specific KO models are to be carried out to further investigate the role of HSD17B12 in the brain development and to understand its putative role in eicosanoid production.

\section{Declaration of interest}

The authors declare that there is no conflict of interest that could be perceived as prejudicing the impartiality of the review reported.

\section{Funding}

This review did not receive any specific grant from any funding agency in the public, commercial or not-for-profit sector.

\section{References}

Abu-Elheiga L, Matzuk MM, Kordari P, Oh W, Shaikenov T, Gu Z \& Wakil SJ 2005 Mutant mice lacking acetyl-CoA carboxylase 1 are embryonically lethal. PNAS 102 12011-12016. (doi:10.1073/pnas.0505714102)

Akinola LA, Poutanen M, Vihko R \& Vihko P 1997 Expression of 17betahydroxysteroid dehydrogenase type 1 and type 2, P450 aromatase, and 20alpha-hydroxysteroid dehydrogenase enzymes in immature, mature, and pregnant rats. Endocrinology 138 2886-2892. (doi:10.1210/en.138.7. 2886)

Alberti S, Schuster G, Parini P, Feltkamp D, Diczfalusy U, Rudling M, Angelin B, Bjorkhem I, Pettersson S \& Gustafsson JA 2001 Hepatic cholesterol metabolism and resistance to dietary cholesterol in LXRbetadeficient mice. Journal of Clinical Investigation 107 565-573. (doi:10.1172/ JCI9794)

Auersperg N, Wong AS, Choi KC, Kang SK \& Leung PC 2001 Ovarian surface epithelium: biology, endocrinology, and pathology. Endocrine Reviews 22 255-288. (doi:10.1210/er.22.2.255)

Azzi A, Rehse PH, Zhu DW, Campbell RL, Labrie F \& Lin SX 1996 Crystal structure of human estrogenic 17 beta-hydroxysteroid dehydrogenase complexed with 17 beta-estradiol. Nature Structural Biology 3 665-668. (doi:10.1038/nsb0896-665)

Bacallao K, Leon L, Gabler F, Soto E, Romero C, Valladares L \& Vega M 2008 In situ estrogen metabolism in proliferative endometria from untreated women with polycystic ovarian syndrome with and without endometrial hyperplasia. Journal of Steroid Biochemistry and Molecular Biology 110 163-169. (doi:10.1016/j.jsbmb.2008.03.031)

Bagi CM, Wood J, Wilkie D \& Dixon B 2008 Effect of 17beta-hydroxysteroid dehydrogenase type 2 inhibitor on bone strength in ovariectomized cynomolgus monkeys. Journal of Musculoskeletal \& Neuronal Interactions 8 267-280.

Bentvelsen FM, Brinkmann AO, van der Schoot P, van der Linden JE, van der Kwast TH, Boersma WJ, Schroder FH \& Nijman JM 1995 Developmental pattern and regulation by androgens of androgen receptor expression in the urogenital tract of the rat. Molecular and Cellular Endocrinology 113 245-253. (doi:10.1016/0303-7207(95)03593-V)

Birch EE, Hoffman DR, Uauy R, Birch DG \& Prestidge C 1998 Visual acuity and the essentiality of docosahexaenoic acid and arachidonic acid in the diet of term infants. Pediatric Research 44 201-209. (doi:10.1203/00006450199808000-00011)

Birch EE, Garfield S, Hoffman DR, Uauy R \& Birch DG 2000 A randomized controlled trial of early dietary supply of long-chain polyunsaturated fatty acids and mental development in term infants. Developmental Medicine and Child Neurology 42 174-181. (doi:10.1017/S00121622 00000311) 
Blanchard PG \& Luu-The V 2007 Differential androgen and estrogen substrates specificity in the mouse and primates type 1217 betahydroxysteroid dehydrogenase. Journal of Endocrinology 194 449-455. (doi:10.1677/JOE-07-0144)

Blomquist CH, Bonenfant M, McGinley DM, Posalaky Z, Lakatua DJ, Tuli-Puri S, Bealka DG \& Tremblay Y 2002 Androgenic and estrogenic 17beta-hydroxysteroid dehydrogenase/17-ketosteroid reductase in human ovarian epithelial tumors: evidence for the type 1,2 and 5 isoforms. Journal of Steroid Biochemistry and Molecular Biology 81 343-351. (doi:10. 1016/S0960-0760(02)00117-6)

Breitling R, Laubner D \& Adamski J 2001a Structure-based phylogenetic analysis of short-chain alcohol dehydrogenases and reclassification of the 17beta-hydroxysteroid dehydrogenase family. Molecular Biology and Evolution 18 2154-2161.

Breitling R, Krazeisen A, Moller G \& Adamski J $2001 b$ 17Betahydroxysteroid dehydrogenase type 7 - an ancient 3-ketosteroid reductase of cholesterogenesis. Molecular and Cellular Endocrinology 171 199-204. (doi:10.1016/S0303-7207(00)00416-0)

Caldas H, Cunningham D, Wang X, Jiang F, Humphries L, Kelley RI \& Herman GE 2005 Placental defects are associated with male lethality in bare patches and striated embryos deficient in the $\mathrm{NAD}(\mathrm{P}) \mathrm{H}$ steroid dehydrogenase-like (NSDHL) enzyme. Molecular Genetics and Metabolism 84 48-60. (doi:10.1016/j.ymgme.2004.08.007)

Casey ML, MacDonald PC \& Andersson S 199417 Beta-hydroxysteroid dehydrogenase type 2: chromosomal assignment and progestin regulation of gene expression in human endometrium. Journal of Clinical Investigation 94 2135-2141. (doi:10.1172/JCI117569)

Chai X, Zhai Y, Popescu G \& Napoli JL 1995a Cloning of a cDNA for a second retinol dehydrogenase type II. Expression of its mRNA relative to type I. Journal of Biological Chemistry 270 28408-28412. (doi:10.1074/jbc. 270.47.28408)

Chai X, Boerman MH, Zhai Y \& Napoli JL 1995 b Cloning of a cDNA for liver microsomal retinol dehydrogenase. A tissue-specific, short-chain alcohol dehydrogenase. Journal of Biological Chemistry 270 3900-3904. (doi:10.1074/jbc.270.8.3900)

Chatzipanteli K, Head C, Megerman J \& Axelrod L 1996 The relationship between plasma insulin level, prostaglandin production by adipose tissue, and blood pressure in normal rats and rats with diabetes mellitus and diabetic ketoacidosis. Metabolism: Clinical and Experimental 45 691-698. (doi:10.1016/S0026-0495(96)90133-X)

Chen Y, Sawyers CL \& Scher HI 2008 Targeting the androgen receptor pathway in prostate cancer. Current Opinion in Pharmacology 8 440-448. (doi:10.1016/j.coph.2008.07.005)

Cheng EJ, Kurman RJ, Wang M, Oldt R, Wang BG, Berman DM \& Shih I 2004 Molecular genetic analysis of ovarian serous cystadenomas. Laboratory Investigation 84 778-784. (doi:10.1038/labinvest.3700103)

Cheng YH, Yin P, Xue Q, Yilmaz B, Dawson MI \& Bulun SE 2008 Retinoic acid (RA) regulates 17beta-hydroxysteroid dehydrogenase type 2 expression in endometrium: interaction of RA receptors with specificity protein (SP) 1/SP3 for estradiol metabolism. Journal of Clinical Endocrinology and Metabolism 93 1915-1923. (doi:10.1210/jc.2007-1536)

Chura JC, Ryu HS, Simard M, Poirier D, Tremblay Y, Brooker DC, Blomquist CH \& Argenta PA 2009 Steroid-converting enzymes in human ovarian carcinomas. Molecular and Cellular Endocrinology 301 51-58. (doi:10. 1016/j.mce.2008.07.015)

Cohlan SQ 1953 Excessive intake of vitamin A as a cause of congenital anomalies in the rat. Science 117 535-536. (doi:10.1126/science.117.3046. 535)

Cook HW, Byers DM, Palmer FB, Spence MW, Rakoff H, Duval SM \& Emken EA 1991 Alternate pathways in the desaturation and chain elongation of linolenic acid, 18:3(n-3), in cultured glioma cells. Journal of Lipid Research 32 1265-1273.

Crawford MA 1993 The role of essential fatty acids in neural development: implications for perinatal nutrition. American Journal of Clinical Nutrition 57 703S-709S.

Crawford MA, Hassam AG \& Williams G 1976 Essential fatty acids and fetal brain growth. Lancet 1 452-453. (doi:10.1016/S0140-6736(76)91476-8)
Dassen H, Punyadeera C, Kamps R, Delvoux B, Van Langendonckt A, Donnez J, Husen B, Thole H, Dunselman G \& Groothuis P 2007 Estrogen metabolizing enzymes in endometrium and endometriosis. Human Reproduction 22 3148-3158. (doi:10.1093/humrep/dem310)

Day JM, Tutill HJ, Purohit A \& Reed MJ 2008a Design and validation of specific inhibitors of 17beta-hydroxysteroid dehydrogenases for therapeutic application in breast and prostate cancer, and in endometriosis. EndocrineRelated Cancer 15 665-692. (doi:10.1677/ERC-08-0042)

Day JM, Foster PA, Tutill HJ, Parsons MF, Newman SP, Chander SK, Allan GM, Lawrence HR, Vicker N, Potter BV et al. 20086 17Betahydroxysteroid dehydrogenase type 1 , and not type 12 , is a target for endocrine therapy of hormone-dependent breast cancer. International Journal of Cancer 122 1931-1940. (doi:10.1002/ijc.23350)

Delvoux B, Husen B, Aldenhoff Y, Koole L, Dunselman G, Thole H \& Groothuis P 2007 A sensitive HPLC method for the assessment of metabolic conversion of estrogens. Journal of Steroid Biochemistry and Molecular Biology 104 246-251. (doi:10.1016/j.jsbmb.2007.03.006)

Delvoux B, Groothuis P, D'Hooghe T, Kyama C, Dunselman G \& Romano A 2009 Increased production of 17 beta-estradiol in endometriosis lesions is the result of impaired metabolism. Journal of Clinical Endocrinology and Metabolism 94 876-883. (doi:10.1210/jc.2008-2218)

Derry JM, Gormally E, Means GD, Zhao W, Meindl A, Kelley RI, Boyd Y \& Herman GE 1999 Mutations in a delta 8-delta 7 sterol isomerase in the tattered mouse and X-linked dominant chondrodysplasia punctata. Nature Genetics 22 286-290. (doi:10.1038/10350)

Duan WR, Linzer DI \& Gibori G 1996 Cloning and characterization of an ovarian-specific protein that associates with the short form of the prolactin receptor. Journal of Biological Chemistry 271 15602-15607. (doi:10.1074/jbc. 271.44.27863)

Elo JP, Akinola LA, Poutanen M, Vihko P, Kyllonen AP, Lukkarinen O \& Vihko R 1996 Characterization of 17beta-hydroxysteroid dehydrogenase isoenzyme expression in benign and malignant human prostate. International Journal of Cancer 66 37-41. (doi:10.1002/(SICI)1097-0215(19960328)66:1 $<37::$ AID-IJC7>3.0.CO;2-)

Entchev EV, Schwudke D, Zagoriy V, Matyash V, Bogdanova A, Habermann B, Zhu L, Shevchenko A \& Kurzchalia TV 2008 LET-767 is required for the production of branched chain and long chain fatty acids in Caenorhabditis elegans . Journal of Biological Chemistry 283 17550-17560. (doi:10.1074/jbc. M800965200)

Fechner S, Husen B, Thole H, Schmidt M, Gashaw I, Kimmig R, Winterhager E \& Grummer R 2007 Expression and regulation of estrogenconverting enzymes in ectopic human endometrial tissue. Fertility and Sterility 88 1029-1038. (doi:10.1016/j.fertnstert.2006.11.153)

Fitzky BU, Moebius FF, Asaoka H, Waage-Baudet H, Xu L, Xu G, Maeda N, Kluckman K, Hiller S, Yu H et al. 2001 7-Dehydrocholesterol-dependent proteolysis of HMG-CoA reductase suppresses sterol biosynthesis in a mouse model of Smith-Lemli-Opitz/RSH syndrome. Journal of Clinical Investigation 108 905-915.

Foster PM \& Harris MW 2005 Changes in androgen-mediated reproductive development in male rat offspring following exposure to a single oral dose of flutamide at different gestational ages. Toxicological Sciences 85 1024-1032. (doi:10.1093/toxsci/kfi159)

Fournier MA \& Poirier D 2009 Estrogen formation in endometrial and cervix cancer cell lines: involvement of aromatase, steroid sulfatase and 17betahydroxysteroid dehydrogenases (types 1, 5, 7 and 12). Molecular and Cellular Endocrinology 301 142-145. (doi:10.1016/j.mce.2008.08.027)

Gaemers IC, van Pelt AM, van der Saag PT \& de Rooij DG 1996 All-trans-4oxo-retinoic acid: a potent inducer of in vivo proliferation of growtharrested A spermatogonia in the vitamin A-deficient mouse testis. Endocrinology 137 479-485. (doi:10.1210/en.137.2.479)

Gaemers IC, Sonneveld E, van Pelt AM, Schrans BH, Themmen AP, van der Saag PT \& de Rooij DG 1998a The effect of 9-cis-retinoic acid on proliferation and differentiation of a spermatogonia and retinoid receptor gene expression in the vitamin A-deficient mouse testis. Endocrinology 139 4269-4276. (doi:10.1210/en.139.10.4269)

Gaemers IC, van Pelt AM, van der Saag PT, Hoogerbrugge JW, Themmen AP \& de Rooij DG 1998 b Differential expression pattern of retinoid X 
receptors in adult murine testicular cells implies varying roles for these receptors in spermatogenesis. Biology of Reproduction 58 1351-1356. (doi:10. 1095/biolreprod58.6.1351)

Galli C \& Spagnuolo C 1976 The release of brain free fatty acids during ischaemia in essential fatty acid-deficient rats. Journal of Neurochemistry 26 401-404. (doi:10.1111/j.1471-4159.1976.tb04493.x)

Gaoua W, Chevy F, Roux C \& Wolf C 1999 Oxidized derivatives of 7-dehydrocholesterol induce growth retardation in cultured rat embryos: a model for antenatal growth retardation in the Smith-Lemli-Opitz syndrome. Journal of Lipid Research 40 456-463.

Ghyselinck NB, Dupe V, Dierich A, Messaddeq N, Garnier JM, RochetteEgly C, Chambon P \& Mark M 1997 Role of the retinoic acid receptor beta (RARbeta) during mouse development. International Journal of Developmental Biology 41 425-447.

Giudice L 2010 Clinical practice. Endometriosis. New England Journal of Medicine 362 2389-2398. (doi:10.1056/NEJMcp1000274)

Goodarzi MO, Dumesic DA, Chazenbalk G \& Azziz R 2011 Polycystic ovary syndrome: etiology, pathogenesis and diagnosis. Nature Reviews. Endocrinology 7 219-331. (doi:10.1038/nrendo.2010.217)

Goto T, Takano M, Albergaria A, Briese J, Pomeranz KM, Cloke B, Fusi L, Feroze-Zaidi F, Maywald N, Sajin M et al. 2008 Mechanism and functional consequences of loss of FOXO1 expression in endometrioid endometrial cancer cells. Oncogene 27 9-19. (doi:10.1038/sj.onc.1210626)

Grondona JM, Kastner P, Gansmuller A, Decimo D, Chambon P \& Mark M 1996 Retinal dysplasia and degeneration in RARbeta2/RARgamma2 compound mutant mice. Development 122 2173-2188.

Haynes BP, Straume AH, Geisler J, A'Hern R, Helle H, Smith IE, Lønning PE \& Dowsett M 2010 Intratumoral estrogen disposition in breast cancer. Clinical Cancer Research 16 1790-1801. (doi:10.1158/1078-0432.CCR-092481)

Hewitt SC, Harrell JC \& Korach KS 2005 Lessons in estrogen biology from knockout and transgenic animals. Annual Review of Physiology 67 285-308. (doi:10.1146/annurev.physiol.67.040403.115914)

Ho SM 2003 Estrogen, progesterone and epithelial ovarian cancer. Reproductive Biology and Endocrinology 1 73. (doi:10.1186/1477-7827-1-73)

Hsieh AC \& Ryan CJ 2008 Novel concepts in androgen receptor blockade. Cancer Journal 14 11-14. (doi:10.1097/PPO.0b013e318161d13e)

Husen B, Huhtinen K, Poutanen M, Kangas L, Messinger J \& Thole H 2006 Evaluation of inhibitors for 17beta-hydroxysteroid dehydrogenase type 1 in vivo in immunodeficient mice inoculated with MCF-7 cells stably expressing the recombinant human enzyme. Molecular and Cellular Endocrinology 248 109-113. (doi:10.1016/j.mce.2005.11.042)

Ito K, Suzuki T, Moriya T, Utsunomiya H, Sugawara A, Konno R, Sato S \& Sasano H 2001 Retinoid receptors in the human endometrium and its disorders: A possible modulator of 17 beta-hydroxysteroid dehydrogenase. Journal of Clinical Endocrinology and Metabolism 86 2721-2727. (doi:10.1210/ jc.86.6.2721)

Jokela H, Rantakari P, Lamminen T, Strauss L, Ola R, Mutka AL, Gylling H, Miettinen T, Pakarinen P, Sainio K et al. 2010 Hydroxysteroid (17beta) dehydrogenase 7 activity is essential for fetal de novo cholesterol synthesis and for neuroectodermal survival and cardiovascular differentiation in early mouse embryos. Endocrinology 151 1884-1892. (doi:10.1210/en.20090928)

Kastner P, Grondona JM, Mark M, Gansmuller A, LeMeur M, Decimo D, Vonesch JL, Dolle P \& Chambon P 1994 Genetic analysis of RXR alpha developmental function: convergence of RXR and RAR signaling pathways in heart and eye morphogenesis. Cell 78 987-1003. (doi:10.1016/ 0092-8674(94)90274-7)

Kastner P, Mark M, Leid M, Gansmuller A, Chin W, Grondona JM, Decimo D, Krezel W, Dierich A \& Chambon P 1996 Abnormal spermatogenesis in RXR beta mutant mice. Genes and Development 10 80-92. (doi:10.1101/gad.10.1.80)

Kerkhofs S, Denayer S, Haelens A \& Claessens F 2009 Androgen receptor knockout and knock-in mouse models. Journal of Molecular Endocrinology 42 11-17. (doi:10.1677/JME-08-0122)

Krakowiak PA, Wassif CA, Kratz L, Cozma D, Kovarova M, Harris G, Grinberg A, Yang Y, Hunter AG, Tsokos M et al. 2003 Lathosterolosis: an inborn error of human and murine cholesterol synthesis due to lathosterol 5-desaturase deficiency. Human Molecular Genetics 12 1631-1641. (doi:10.1093/hmg/ddg172)

Labrie F 2007 Drug insight: breast cancer prevention and tissue-targeted hormone replacement therapy. Nature Clinical Practice. Endocrinology \& Metabolism 3 584-593. (doi:10.1038/ncpendmet0559)

Labrie Y, Durocher F, Lachance Y, Turgeon C, Simard J, Labrie C \& Labrie F 1995 The human type II 17 beta-hydroxysteroid dehydrogenase gene encodes two alternatively spliced mRNA species. DNA and Cell Biology 14 849-861. (doi:10.1089/dna.1995.14.849)

Lamminen T, Saloniemi T, Huhtinen K, Koskimies P, Messinger J, Husen B, Thole H \& Poutanen M 2009 In vivo mouse model for analysis of hydroxysteroid (17beta) dehydrogenase 1 inhibitors. Molecular and Cellular Endocrinology 301 158-162. (doi:10.1016/j.mce.2008.10.034)

van Landeghem AA, Poortman J, Nabuurs M \& Thijssen JH 1985 Endogenous concentration and subcellular distribution of androgens in normal and malignant human breast tissue. Cancer Research 45 2907-2912.

Laplante Y, Rancourt C \& Poirier D 2009 Relative involvement of three 17beta-hydroxysteroid dehydrogenases (types 1, 7 and 12) in the formation of estradiol in various breast cancer cell lines using selective inhibitors. Molecular and Cellular Endocrinology 301 146-153. (doi:10.1016/j.mce.2008. 08.026)

Laubner D, Breitling R \& Adamski J 2003 Embryonic expression of cholesterogenic genes is restricted to distinct domains and colocalizes with apoptotic regions in mice. Brain Research 115 87-92. (doi:10.1016/S0169328X(03)00094-9)

Leaf AA, Leighfield MJ, Costeloe KL \& Crawford MA 1992 Long chain polyunsaturated fatty acids and fetal growth. Early Human Development 30 183-191. (doi:10.1016/0378-3782(92)90068-R)

Leon L, Bacallao K, Gabler F, Romero C, Valladares L \& Vega M 2008 Activities of steroid metabolic enzymes in secretory endometria from untreated women with polycystic ovary syndrome. Steroids 73 88-95. (doi:10.1016/j.steroids.2007.09.003)

Li X, Wärri A, Mäkelä S, Ahonen T, Streng T, Santti R \& Poutanen M 2002 Mammary gland development in transgenic male mice expressing human P450 aromatase. Endocrinology 143 4074-4083. (doi:10.1210/en.2002220181)

Lin SX, Shi R, Qiu W, Azzi A, Zhu DW, Dabbagh HA \& Zhou M 2006 Structural basis of the multispecificity demonstrated by 17 betahydroxysteroid dehydrogenase types 1 and 5. Molecular and Cellular Endocrinology 248 38-46. (doi:10.1016/j.mce.2005.11.035)

Liu XY, Dangel AW, Kelley RI, Zhao W, Denny P, Botcherby M, Cattanach B, Peters J, Hunsicker PR, Mallon AM et al. 1999 The gene mutated in bare patches and striated mice encodes a novel 3beta-hydroxysteroid dehydrogenase. Nature Genetics 22 182-187. (doi:10.1038/9700)

Liu H, Robert A \& Luu-The V 2005 Cloning and characterization of human form 2 type 7 17beta-hydroxysteroid dehydrogenase, a primarily 3betaketo reductase and estrogen activating and androgen inactivating enzyme. Journal of Steroid Biochemistry and Molecular Biology 94 173-179. (doi:10. 1016/j.jsbmb.2005.01.023)

Lohnes D, Kastner P, Dierich A, Mark M, LeMeur M \& Chambon P 1993 Function of retinoic acid receptor gamma in the mouse. Cell 73 643-658. (doi:10.1016/0092-8674(93)90246-M)

Lohnes D, Mark M, Mendelsohn C, Dolle P, Dierich A, Gorry P, Gansmuller A \& Chambon P 1994 Function of the retinoic acid receptors (RARs) during development (I). Craniofacial and skeletal abnormalities in RAR double mutants. Development 120 2723-2748.

Lønning PE, Helle H, Duong NK, Ekse D, Aas T \& Geisler J 2009 Tissue estradiol is selectively elevated in receptor positive breast cancers while tumour estrone is reduced independent of receptor status. Journal of Steroid Biochemistry and Molecular Biology 117 31-41. (doi:10.1016/j.jsbmb.2009. 06.005)

Lufkin T, Lohnes D, Mark M, Dierich A, Gorry P, Gaub MP, LeMeur M \& Chambon P 1993 High postnatal lethality and testis degeneration in retinoic acid receptor alpha mutant mice. PNAS 90 7225-7229. (doi:10. 1073 /pnas.90.15.7225) 
Lukacik P, Kavanagh KL \& Oppermann U 2006 Structure and function of human 17beta-hydroxysteroid dehydrogenases. Molecular and Cellular Endocrinology 248 61-71. (doi:10.1016/j.mce.2005.12.007)

Luu-The V, Tremblay P \& Labrie F 2006 Characterization of type 12 17betahydroxysteroid dehydrogenase, an isoform of type 3 17beta-hydroxysteroid dehydrogenase responsible for estradiol formation in women. Molecular Endocrinology 20 437-443. (doi:10.1210/me.2005-0058)

Mäentausta O, Sormunen R, Isomaa V, Lehto VP, Jouppila P \& Vihko R 1991 Immunohistochemical localization of 17 beta-hydroxysteroid dehydrogenase in the human endometrium during the menstrual cycle. Laboratory Investigation 65 582-587.

Mäentausta O, Boman K, Isomaa V, Stendahl U, Backstrom T \& Vihko R 1992 Immunohistochemical study of the human 17 beta-hydroxysteroid dehydrogenase and steroid receptors in endometrial adenocarcinoma. Cancer 70 1551-1555. (doi:10.1002/1097-0142(19920915)70:6< 1551::AID-CNCR2820700618>3.0.CO;2-)

Mahendroo MS, Cala KM, Landrum DP \& Russell DW 1997 Fetal death in mice lacking 5alpha-reductase type 1 caused by estrogen excess. Molecular Endocrinology 11 917-927. (doi:10.1210/me.11.7.917)

Marijanovic Z, Laubner D, Moller G, Gege C, Husen B, Adamski J \& Breitling R 2003 Closing the gap: identification of human 3-ketosteroid reductase, the last unknown enzyme of mammalian cholesterol biosynthesis. Molecular Endocrinology 17 1715-1725. (doi:10.1210/me.2002-0436)

Matsumoto T, Takeyama K, Sato T \& Kato S 2003 Androgen receptor functions from reverse genetic models. Journal of Steroid Biochemistry and Molecular Biology 85 95-99. (doi:10.1016/S0960-0760(03)00231-0)

Meier M, Möller G \& Adamski J 2009 Perspectives in understanding the role of human 17beta-hydroxysteroid dehydrogenases in health and disease. Annals of the New York Academy of Sciences 1155 15-24. (doi:10.1111/j.17496632.2009.03702.x)

Merke DP \& Bornstein SR 2005 Congenital adrenal hyperplasia. Lancet 365 2125-2136. (doi:10.1016/S0140-6736(05)66736-0)

Miettinen MM, Mustonen MV, Poutanen MH, Isomaa VV \& Vihko RK 1996a Human 17 beta-hydroxysteroid dehydrogenase type 1 and type 2 isoenzymes have opposite activities in cultured cells and characteristic cell- and tissue-specific expression. Biochemical Journal 314 839-845.

Miettinen MM, Poutanen MH \& Vihko RK $1996 b$ Characterization of estrogen-dependent growth of cultured MCF-7 human breast-cancer cells expressing 17beta-hydroxysteroid dehydrogenase type 1. International Journal of Cancer 68 600-604. (doi:10.1002/(SICI)1097-0215(19961127) $68: 5<600::$ AID-IJC8 $>3.0$. CO;2-2)

Mindnich R \& Adamski J 2009 Zebrafish 17beta-hydroxysteroid dehydrogenases: an evolutionary perspective. Molecular and Cellular Endocrinology 301 20-26. (doi:10.1016/j.mce.2008.12.002)

Mindnich R, Deluca D \& Adamski J 2004 Identification and characterization of 17 beta-hydroxysteroid dehydrogenases in the zebrafish, Danio rerio. Molecular and Cellular Endocrinology 215 19-30. (doi:10.1016/j.mce.2003. 11.010)

Mirza R, Hayasaka S, Takagishi Y, Kambe F, Ohmori S, Maki K, Yamamoto M, Murakami K, Kaji T, Zadworny D et al. 2006 DHCR24 gene knockout mice demonstrate lethal dermopathy with differentiation and maturation defects in the epidermis. Journal of Investigative Dermatology 126 638-647. (doi:10. 1038/sj.jid.5700111)

Miyata K, Yabushita S, Sukata T, Sano M, Yoshino H, Nakanishi T, Okuno Y \& Matsuo M 2002 Effects of perinatal exposure to flutamide on sex hormones and androgen-dependent organs in F1 male rats. Journal of Toxicological Sciences 27 19-33. (doi:10.2131/jts.27.19)

Miyoshi Y, Ando A, Shiba E, Taguchi T, Tamaki Y \& Noguchi S 2001 Involvement of up-regulation of 17beta-hydroxysteroid dehydrogenase type 1 in maintenance of intratumoral high estradiol levels in postmenopausal breast cancers. International Journal of Cancer 94 685-689. (doi:10.1002/ijc.1525)

Möller G \& Adamski J 2006 Multifunctionality of human 17betahydroxysteroid dehydrogenases. Molecular and Cellular Endocrinology 248 4755. (doi:10.1016/j.mce.2005.11.031)

Möller G \& Adamski J 2009 Integrated view on 17beta-hydroxysteroid dehydrogenases. Molecular and Cellular Endocrinology 301 7-19. (doi:10. 1016/j.mce.2008.10.040)
Moon YA \& Horton JD 2003 Identification of two mammalian reductases involved in the two-carbon fatty acyl elongation cascade. Journal of Biological Chemistry 278 7335-7343. (doi:10.1074/jbc.M211684200)

Mustonen MV, Poutanen MH, Isomaa VV, Vihko PT \& Vihko RK 1997 a Cloning of mouse 17beta-hydroxysteroid dehydrogenase type 2 , and analysing expression of the mRNAs for types 1, 2, 3, 4 and 5 in mouse embryos and adult tissues. Biochemical Journal 325 199-205.

Mustonen M, Poutanen M, Chotteau-Lelievre A, de Launoit Y, Isomaa V, Vainio S, Vihko R \& Vihko P $1997 b$ Ontogeny of 17beta-hydroxysteroid dehydrogenase type 2 mRNA expression in the developing mouse placenta and fetus. Molecular and Cellular Endocrinology 134 33-40. (doi:10.1016/ S0303-7207(97)00157-3)

Mustonen MV, Poutanen MH, Kellokumpu S, de Launoit Y, Isomaa VV, Vihko RK \& Vihko PT 1998a Mouse 17 beta-hydroxysteroid dehydrogenase type 2 mRNA is predominantly expressed in hepatocytes and in surface epithelial cells of the gastrointestinal and urinary tracts. Journal of Molecular Endocrinology 20 67-74. (doi:10.1677/jme.0.0200067)

Mustonen MV, Isomaa VV, Vaskivuo T, Tapanainen J, Poutanen MH, Stenback F, Vihko RK \& Vihko PT 1998b Human 17beta-hydroxysteroid dehydrogenase type 2 messenger ribonucleic acid expression and localization in term placenta and in endometrium during the menstrual cycle. Journal of Clinical Endocrinology and Metabolism 83 1319-1324. (doi:10. $1210 /$ jc.83.4.1319)

Nagasaki S, Miki Y, Akahira J, Suzuki T \& Sasano H 2009 Transcriptional regulation of 17beta-hydroxysteroid dehydrogenase type 12 by SREBP-1. Molecular and Cellular Endocrinology 307 163-168. (doi:10.1016/j.mce.2009. 04.002)

Nokelainen P, Puranen T, Peltoketo H, Orava M, Vihko P \& Vihko R 1996 Molecular cloning of mouse 17 beta-hydroxysteroid dehydrogenase type 1 and characterization of enzyme activity. European Journal of Biochemistry 236 482-490. (doi:10.1111/j.1432-1033.1996.00482.x)

Nokelainen P, Peltoketo H, Vihko R \& Vihko P 1998 Expression cloning of a novel estrogenic mouse 17 beta-hydroxysteroid dehydrogenase/ 17-ketosteroid reductase (m17HSD7), previously described as a prolactin receptor-associated protein (PRAP) in rat. Molecular Endocrinology 12 1048-1059. (doi:10.1210/me.12.7.1048)

Nokelainen P, Peltoketo H, Mustonen M \& Vihko P 2000 Expression of mouse 17beta-hydroxysteroid dehydrogenase/17-ketosteroid reductase type 7 in the ovary, uterus, and placenta: localization from implantation to late pregnancy. Endocrinology 141 772-778. (doi:10.1210/en.141.2.772)

Olsen CM, Green AC, Nagle CM, Jordan SJ, Whiteman DC, Bain CJ \& Webb PM 2008 Australian Cancer Study Group (ovarian cancer) and the Australian Ovarian Cancer Study Group epithelial ovarian cancer: testing the androgens hypothesis. Endocrine-Related Cancer 15 1061-1068. (doi:10. 1677/ERC-08-0075)

Peltoketo H, Luu-The V, Simard J \& Adamski J 1999a 17Beta-hydroxysteroid dehydrogenase (HSD)/17-ketosteroid reductase (KSR) family; nomenclature and main characteristics of the 17HSD/KSR enzymes. Journal of Molecular Endocrinology 23 1-11. (doi:10.1677/jme.0.0230001)

Peltoketo H, Nokelainen P, Piao YS, Vihko R \& Vihko P 1999 b Two 17betahydroxysteroid dehydrogenases (17HSDs) of estradiol biosynthesis: 17HSD type 1 and type 7. Journal of Steroid Biochemistry and Molecular Biology 69 431-439. (doi:10.1016/S0960-0760(99)00064-3)

Persson B, Kallberg Y, Bray JE, Bruford E, Dellaporta SL, Favia AD, Duarte RG, Jornvall H, Kavanagh KL, Kedishvili N et al. 2009 The SDR (short-chain dehydrogenase/reductase and related enzymes) nomenclature initiative. Chemico-Biological Interactions 178 94-98. (doi:10. 1016/j.cbi.2008.10.040)

Poutanen M, Miettinen M \& Vihko R 1993 Differential estrogen substrate specificities for transiently expressed human placental 17 beta-hydroxysteroid dehydrogenase and an endogenous enzyme expressed in cultured COS-m6 cells. Endocrinology 133 2639-2644. (doi:10.1210/en.133.6.2639)

Puranen T, Poutanen M, Ghosh D, Vihko R \& Vihko P 1997 Origin of substrate specificity of human and rat 17beta-hydroxysteroid dehydrogenase type 1, using chimeric enzymes and site-directed substitutions. Endocrinology 138 3532-3539. (doi:10.1210/en.138.8.3532)

Rantakari P, Strauss L, Kiviranta R, Lagerbohm H, Paviala J, Holopainen I, Vainio S, Pakarinen P \& Poutanen M 2008 Placenta defects and embryonic 
lethality resulting from disruption of mouse hydroxysteroid (17-beta) dehydrogenase 2 gene. Molecular Endocrinology 22 665-675. (doi:10.1210/ me.2007-0257)

Rantakari P, Lagerbohm H, Kaimainen M, Suomela JP, Strauss L, Sainio K, Pakarinen P \& Poutanen M 2010 Hydroxysteroid (17\{beta\}) dehydrogenase 12 is essential for mouse organogenesis and embryonic survival. Endocrinology 151 1893-1901. (doi:10.1210/en.2009-0929)

Rizner TL, Smuc T, Rupreht R, Sinkovec J \& Penning TM 2006 AKR1C1 and AKR1C3 may determine progesterone and estrogen ratios in endometrial cancer. Molecular and Cellular Endocrinology 248 126-135. (doi:10.1016/j.mce.2005.10.009)

Sakurai N, Miki Y, Suzuki T, Watanabe K, Narita T, Ando K, Yung TM, Aoki D, Sasano H \& Handa H 2006 Systemic distribution and tissue localizations of human 17beta-hydroxysteroid dehydrogenase type 12. Journal of Steroid Biochemistry and Molecular Biology 99 174-181. (doi:10.1016/j.jsbmb.2006.01. 010)

Saloniemi T, Lamminen T, Huhtinen K, Welsh M, Saunders P, Kujari H \& Poutanen M 2007 Activation of androgens by hydroxysteroid (17beta) dehydrogenase 1 in vivo as a cause of prenatal masculinization and ovarian benign serous cystadenomas. Molecular Endocrinology 21 2627-2636. (doi:10. 1210/me.2007-0144)

Saloniemi T, Welsh M, Lamminen T, Saunders P, Mäkelä S, Streng T \& Poutanen M 2009 Human HSD17B1 expression masculinizes transgenic female mice. Molecular and Cellular Endocrinology 301 163-168. (doi:10. 1016/j.mce.2008.10.047)

Saloniemi T, Järvensivu P, Koskimies P, Jokela H, Lamminen T, Ghaem-Maghami S, Dina R, Damdimopoulou P, Mäkelä S, Perheentupa A et al. 2010 Novel hydroxysteroid (17beta) dehydrogenase 1 inhibitors reverse estrogen-induced endometrial hyperplasia in transgenic mice. American Journal of Pathology 176 1443-1451. (doi:10.2353/ajpath.2010. 090325)

Sano T, Hirasawa G, Takeyama J, Darnel AD, Suzuki T, Moriya T, Kato K, Sekine H, Ohara S, Shimosegawa T et al. 200117 Beta-hydroxysteroid dehydrogenase type 2 expression and enzyme activity in the human gastrointestinal tract. Clinical Science 101 485-491. (doi:10.1042/ CS20010052)

Santos FC, Leite RP, Custodio AM, Carvalho KP, Monteiro-Leal LH, Santos AB, Goes RM, Carvalho HF \& Taboga SR 2006 Testosterone stimulates growth and secretory activity of the female prostate in the adult gerbil (Meriones unguiculatus). Biology of Reproduction 75 370-379. (doi:10.1095/ biolreprod.106.051789)

Sasano H, Suzuki T, Niikura H, Kaga K, Sato S, Yajima A, Rainey WE \& Nagura H 199617 beta-hydroxysteroid dehydrogenase in common epithelial ovarian tumors. Modern Pathology 9 386-391.

Sasano H, Nagasaki S, Miki Y \& Suzuki T 2009 New developments in intracrinology of human breast cancer: estrogen sulfatase and sulfotransferase. Annals of the New York Academy of Sciences 1155 76-79. (doi:10.1111/ j.1749-6632.2008.03683.x)

Schrans-Stassen BH, van de Kant HJ, de Rooij DG \& van Pelt AM 1999 Differential expression of $\mathrm{c}$-kit in mouse undifferentiated and differentiating type A spermatogonia. Endocrinology 140 5894-5900. (doi:10.1210/en.140. 12.5894)

Shehu A, Mao J, Gibori GB, Halperin J, Le J, Devi YS, Merrill B, Kiyokawa H \& Gibori G 2008 Prolactin receptor-associated protein/17beta-hydroxysteroid dehydrogenase type 7 gene (Hsd17b7) plays a crucial role in embryonic development and fetal survival. Molecular Endocrinology 22 2268-2277. (doi:10.1210/me.2008-0165)

Shen Z, Saloniemi T, Rönnblad A, Järvensivu P, Pakarinen P \& Poutanen M 2009 Sex steroid-dependent and -independent action of hydroxysteroid (17beta) dehydrogenase 2: evidence from transgenic female mice. Endocrinology 150 4941-4949. (doi:10.1210/en.2009-0670)

Shibuya R, Suzuki T, Miki Y, Yoshida K, Moriya T, Ono K, Akahira J, Ishida T, Hirakawa H, Evans DB et al. 2008 Intratumoral concentration of sex steroids and expression of sex steroid-producing enzymes in ductal carcinoma in situ of human breast. Endocrine-Related Cancer 15 113-124. (doi:10.1677/ERC-07-0092)
Simon A, Hellman U, Wernstedt C \& Eriksson U 1995 The retinal pigment epithelial-specific 11-cis-retinol dehydrogenase belongs to the family of short chain alcohol dehydrogenases. Journal of Biological Chemistry 270 1107-1112. (doi:10.1074/jbc.270.3.1107)

Sinclair AJ \& Crawford MA 1973 The effect of a low-fat maternal diet on neonatal rats. British Journal of Nutrition 29 127-137. (doi:10.1079/ BJN19730085)

Smuc T, Rupreht R, Sinkovec J, Adamski J \& Rizner TL 2006 Expression analysis of estrogen-metabolizing enzymes in human endometrial cancer. Molecular and Cellular Endocrinology 248 114-117. (doi:10.1016/j.mce.2005. 10.013)

Stinnakre MG 1975 Period of sensitivity to androgens of the Wolff duct of the rat fetus. Archives d'Anatomie Microscopique et de Morphologie Expérimentale 64 45-59.

Su EJ, Cheng YH, Chatterton RT, Lin ZH, Yin P, Reierstad S, Innes J \& Bulun SE 2007 Regulation of 17-beta hydroxysteroid dehydrogenase type 2 in human placental endothelial cells. Biology of Reproduction 77 517-525. (doi:10.1095/biolreprod.106.059451)

Syed V, Ulinski G, Mok SC, Yiu GK \& Ho SM 2001 Expression of gonadotropin receptor and growth responses to key reproductive hormones in normal and malignant human ovarian surface epithelial cells. Cancer Research 61 6768-6776.

Tint GS, Yu H, Shang Q, Xu G \& Patel SB 2006 The use of the Dhcr7 knockout mouse to accurately determine the origin of fetal sterols. Journal of Lipid Research 47 1535-1541. (doi:10.1194/jlr.M600141JLR200)

Tong MH, Jiang H, Liu P, Lawson JA, Brass LF \& Song WC 2005 Spontaneous fetal loss caused by placental thrombosis in estrogen sulfotransferase-deficient mice. Nature Medicine 11 153-159. (doi:10.1038/ nm1184)

Torn S, Nokelainen P, Kurkela R, Pulkka A, Menjivar M, Ghosh S, Coca-Prados M, Peltoketo H, Isomaa V \& Vihko P 2003 Production, purification, and functional analysis of recombinant human and mouse 17beta-hydroxysteroid dehydrogenase type 7. Biochemical and Biophysical Research Communications 305 37-45. (doi:10.1016/S0006-291X(03) 00694-6)

Tozawa R, Ishibashi S, Osuga J, Yagyu H, Oka T, Chen Z, Ohashi K, Perrey S, Shionoiri F, Yahagi N et al. 1999 Embryonic lethality and defective neural tube closure in mice lacking squalene synthase. Journal of Biological Chemistry 274 30843-30848. (doi:10.1074/jbc.274.43.30843)

Wainwright PE, Xing HC, Mutsaers L, McCutcheon D \& Kyle D 1997 Arachidonic acid offsets the effects on mouse brain and behavior of a diet with a low $(n-6):(n-3)$ ratio and very high levels of docosahexaenoic acid. Journal of Nutrition 127 184-193.

Wechsler A, Brafman A, Shafir M, Heverin M, Gottlieb H, Damari G, Gozlan-Kelner S, Spivak I, Moshkin O, Fridman E et al. 2003 Generation of viable cholesterol-free mice. Science 302 2087. (doi:10.1126/science. 1090776)

Welsh M, Saunders PT, Fisken M, Scott HM, Hutchison GR, Smith LB \& Sharpe RM 2008 Identification in rats of a programming window for reproductive tract masculinization, disruption of which leads to hypospadias and cryptorchidism. Journal of Clinical Investigation 118 1479-1490. (doi:10. 1172/JCI34241)

Wolf CJ, Hotchkiss A, Ostby JS, LeBlanc GA \& Gray LE Jr 2002 Effects of prenatal testosterone propionate on the sexual development of male and female rats: a dose-response study. Toxicological Sciences 65 71-86. (doi:10. 1093/toxsci/65.1.71)

Wolf CJ, LeBlanc GA \& Gray LE Jr 2004 Interactive effects of vinclozolin and testosterone propionate on pregnancy and sexual differentiation of the male and female SD rat. Toxicological Sciences 78 135-143. (doi:10.1093/toxsci/ kfh018)

Wu L, Einstein M, Geissler WM, Chan HK, Elliston KO \& Andersson S 1993 Expression cloning and characterization of human 17 beta-hydroxysteroid dehydrogenase type 2, a microsomal enzyme possessing 20 alphahydroxysteroid dehydrogenase activity. Journal of Biological Chemistry 268 12964-12969. 
Wu X, Lukacik P, Kavanagh KL \& Oppermann U 2007 SDR-type human hydroxysteroid dehydrogenases involved in steroid hormone activation. Molecular and Cellular Endocrinology 265-266 71-76. (doi:10.1016/j.mce. 2006.12.006)

Yang C, McDonald JG, Patel A, Zhang Y, Umetani M, Xu F, Westover EJ, Covey DF, Mangelsdorf DJ, Cohen JC et al. 2006 Sterol intermediates from cholesterol biosynthetic pathway as liver $\mathrm{X}$ receptor ligands. Journal of Biological Chemistry 281 27816-27826. (doi:10.1074/jbc.M603781200)

Zeitoun K, Takayama K, Sasano H, Suzuki T, Moghrabi N, Andersson S, Johns A, Meng L, Putman M, Carr B et al. 1998 Deficient 17betahydroxysteroid dehydrogenase type 2 expression in endometriosis: failure to metabolize 17beta-estradiol. Journal of Clinical Endocrinology and Metabolism 83 4474-4480. (doi:10.1210/jc.83.12.4474)
Zhao C, Dahlman-Wright K \& Gustafsson JA 2008 Estrogen receptor beta: an overview and update. Nuclear Receptor Signaling 6 e003.

Zhongyi S, Rantakari P, Lamminen T, Toppari J \& Poutanen M 2007

Transgenic male mice expressing human hydroxysteroid dehydrogenase 2 indicate a role for the enzyme independent of its action on sex steroids.

Endocrinology 148 3827-3836. (doi:10.1210/en.2007-0365)

Received in final form 31 October 2011

Accepted 1 November 2011

Made available online as an Accepted Preprint 1 November 2011 